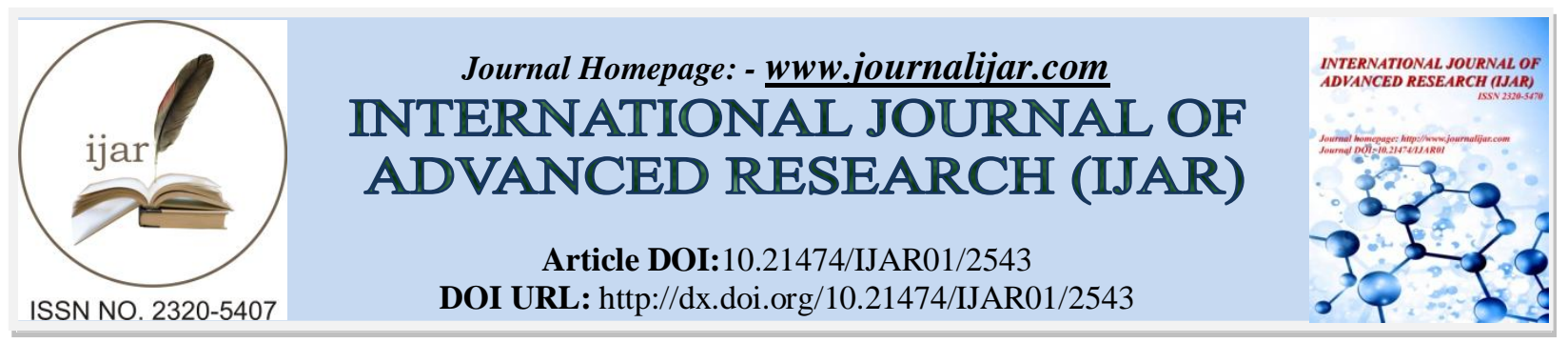

RESEARCH ARTICLE

\title{
SMALL SCALE SECTOR IN TIMES OF GLOBALISATION:A STUDY OF INDIA'S SMALL SCALE SECTOR.
}

\author{
Rakesh Kumar \\ Assistant professor, Department of economics Maharaja Agrasen college University of Delhi.
}

\begin{abstract}
Manuscript Info
Manuscript History

Received: 25 October 2016

Final Accepted: 23 November 2016

Published: December 2016

Key words:-

Industrialisation, small scale sector globalisation.

\section{Abstract}

Industrialisation is the backbone for the economic development of any country. Within that small scale sector is very important sector. For a country like India where labour is surplus, regional disparities are very wide, income inequalities are high, skill sets are low, small scale sector becomes even more important. After globalisation there is a need to revisit many aspects of small scale sector. For that it is necessary we study the various characteristics and their changing nature so that right kind of policies can be formed for the small scale sector
\end{abstract}

Copy Right, IJAR, 2016,. All rights reserved.

Indian economy is the fastest growing economy of the world. In absolute terms ,it is $10^{\text {th }}$ largesteconomy of the world and $4^{\text {th }}$ largest in terms of purchasing power parity terms. Our development experience has also proved that we have defied the path followed by todays developed countries. We have never experienced the second stage of largest contribution of industries to total GDP and employment. Earlier it was agriculture and now service sector for income generation and for employment purposes agriculture is still largest contributor. Unemployment levels in India are stillvery high. We see large income inequalities. We also find thatmodern economic growth have bypassed the unskilled, semiskilled, uneducated, and less educated.. Importance of agriculture has decreased for income generation but at the same time we are not able to transfer the man power from agriculture to manufacture sector, reason being underdeveloped manufacturing sector.

Within the industries MSME can play a major role in solving India's many problems like income inequalities, regional disparities, unemployment, empowerment of women and poor, etc.This is because MSMEs are less capital and skill intensive. They use local resources more intensively.

Importance of MSMEs can be judged from the fact that Small and Medium Enterprises contribute $45 \%$ of the industrial output, $40 \%$ of exports, 42 million in employment, create one million jobs every year. So to solve majority problems of India, we need to shift our focus on MSMEs. Infact Small and medium enterprises are the backbone of industrial development. In terms of

Employment generated in this sector is next only to agriculture.SMEs play a critical-role in generating millions of jobs, especially at the low skill levels. Overall, the small industry sector has done quitewell and has enabled the country to achieve considerable industrial growth and diversification. Small scale industries are less capital intensive and suit the Indian economic environment with scarce resources and large population base. The bad thing is that SMEs in India due to their low scale and poor adoption of technology have very poor productivity.

Economic policy of India hasgone major transformation following the economic crisis of 1991. Though first wave of reforms came in mid 80s, but actual transformation started only after 1991. Since then Indiais continuously 
integrating with the outer world and this has forced many economic policy changes. Over all these changes can be summarized through policy of LPG. Policy of LPG has created vast opportunities for India in general and industrial sector in particular. This has opened the vast landscape of innovations and technical upgradation. But all sectors are not befitted equally. Some other sectors like MSME have been exposed to threats and challenges. Earlier small scale sector was getting protection from government, now these protections are either withdrawn completely or have diminished in significance. This has led to rethinking for small scale sector.

In this paper we try to gauge thechallenges before MSME Sector and thechange that have occurred for MSME after economic reforms of 1991. We also endeavor to discuss various organizational and promotional structures for MSME in India.

\section{Definitional aspect of MSME sector:-}

Definition of small scale industry has changed many times in India. In 1950 it was defined on the basis of number of people employed in the enterprises with or without power. In 1950, thesewere grouped into two categories- those using power but employing less than 50 persons and those not using power but employing less 100 persons.

Another criterion to define small scale industries was on the basis of fixes capital investment in plant and machineryand since 1966 this has changed many times.After economic reforms due to changed scenario and competition from large and foreign companies, a need was felt to revisit the investment limit in small scale sector. As with existing limits on investment small sector was finding it difficult to upgrade and compete with other large industries. In 1997, on the basis of recommendations of Abid Hussian committee, this limit was redefined as investment in plant and machinery for small units and ancillaries less than 3 crore and for tiny units less than 251 lacs. In 2000 this limit was reduced to 1 crore forsmall unit and limit for tiny units were left unchanged.

In 2006 a major shift took place in the approach of government of India. Till now only tiny/micro and small units were defined and there was no definition for medium units. Another problem with earlier was that it has not defined small service enterprises separately. After economic reforms, we see rapid emergence of service sector in India. In fact, Indian economy is service sector led economy. This necessitated the change regarding the view for small sector. So in 2006, GOI, through MSME ACT 2006 rectified this mistake and both manufacturing and service enterprises were defined for all three categories ie. Micro, small and medium. The act is aimed at facilitating the growth of small enterprises so that they graduate to medium enterprises, thus improving their competitive strength.

According to MSME ACT 2006defintions are as follows:-

Micro Enterprise:- A micro enterprise is, where the investment in plant and machinery does notExceed twenty five lakh rupees for manufacturing units and rupee 10 lakh for service enterprises;

Small Enterprise:- A small enterprise is, where the investment in plant and machinery is morethan twenty five lakh rupees but does not exceed five core rupees for manufacturing units and for service enterprises this limit is more than 10 lakh but less than 2 crore.

Medium Enterprise:- A medium enterprise, where the investment in plant and Machinery isMore than five crore rupees but does not exceed ten crore rupees for services for manufacturing units and for units in service sector this is more than 2 crore but less than 5 crore.

This definition is definitely an improvement over earlier definitions but suffers from many short coming. First it does not differentiate between product lines.A unit working inpickle industry cannot be compared with a unit in computer hardware manufacturing. So to fix equal investment limit for all product lines does not make a sense. There is a need to look into this aspect of definition. MSMEs must be clubbed on the basis of product lines and for each product line separate limits shall defined. Secondly there is no inbuilt mechanism in the definition to revise it up automatically. Investment limits are not changed for a quite long period oftime. AsIndia is a very fast growing economy and income level are increasing very rapidly. Inflationlevels are also very high as in all developingeconomy.No change in investment limit for a period of 5 years also can go against the MSMEs. They would not be able to make new investment as they would lose their of MSME status and with that many benefits received by them. Not only that this would make them non-competitive in the market. As price index hasrisen in India, We should revisit MSMEdefinition and shall evolve a mechanism to couple investment limits with price index. Though more than 10 years have passed, still there is no change in the investment limits. To address this 
problem a bill Micro, Small and Medium Enterprises Development (Amendment) Bill, 2015 was introduced in the Lok Sabha on 20.04.2015. This is pending in parliament. The objectives of the proposed amendments are to:

1. Enhance the existing limit for investment in plant and machinery considering changes in price index and cost of inputs consistent with the emerging role of the MSMEs invarious Global Value Chains.

2. Include medium enterprises apart from small enterprises in section 7(9) to enable the aforesaid category of enterprises to avail the benefits and become competitive.

3. Empower the central Government to revise the existing limit for investment by notification, considering the inflation and dynamic market situation

Through this proposals for investment limits for MSME are as follows

1. A micro enterprise where the investment in plant and machinery does not exceed fifty lakhs rupees;

2. A small enterprise where the investment in plant and machinery is more than fifty lakhs rupees but does not exceed ten crores rupees;

3. A medium enterprise where the investment in plant and machinery is more than ten crore rupees but does not exceed thirty crore rupees.

Growth and performance of MSME in India:-

To study the growth and performance in India in a comprehensive way, till now four All India census on small scale industry have been conducted. First census was in 1977, second was in 1987-88. Third All India Census of Small Scale Industries (SSI) was conducted with reference year 2001-02. The Census covered both Registered and Unregistered Sectors for the first time. The census adopted different methodology for Registered and Unregistered Sectors. With the enactment of MSME act 2006, a need was felt to collect data afresh , as no data was available for medium enterprises and service sector units. For this purpose a census was conducted on Micro, Small and Medium Enterprises (MSME) known as Fourth All India Census of MSME 2006-07. The data was collected till 2009, results of which were published in 2011-12. The census adopted different methodology for Registered and Unregistered Sectors. While complete enumeration of enterprises was adopted in Registered Sector, Sample Survey was resorted to in Unregistered Sector. However, for activities under Wholesale/Retail trade, legal, educational \& social services, hotel \& restaurants, transports and storage \& warehousing (except cold storage), which were excluded from the coverage of Fourth All India Census of MSME 2006-07, data was extracted from Economic Census 2005 conducted by Central Statistics Office, Ministry of Statistics and Programme Implementation for finalising the report on MSME Sector. A comparison between $3^{\text {rd }}$ and $4^{\text {th }}$ all India censuses is given below.

Comparison between $3^{\text {rd }}$ and $4^{\text {th }}$ census on small scale sector

\begin{tabular}{|l|l|l|l|l|l|}
\hline $\begin{array}{l}\text { Sl. } \\
\text { No. }\end{array}$ & Characteristics & $\begin{array}{l}\text { Third } \\
\text { Census } \\
(2001-02) \\
\text { (Numbers) }\end{array}$ & $\begin{array}{l}\text { Fourth } \\
\text { Census } \\
(2006-07) \\
\text { (Numbers) }\end{array}$ & $\begin{array}{l}\text { Third } \\
\text { Census } \\
(2001-02) \\
\text { (Percent) }\end{array}$ & $\begin{array}{l}\text { Fourth } \\
\text { Census } \\
(2006-07) \\
\text { (Percent) }\end{array}$ \\
\hline 1 & Size of the Sector(in Lakh) & 91.46 & 198.74 & 100 & 100 \\
\hline 2 & Number of Rural Units(in Lakh) & 51.99 & 119.69 & 56.84 & 60.22 \\
\hline 3 & Number of Urban Units(in Lakh) & 39.47 & 79.05 & 43.16 & 39.78 \\
\hline 4 & Micro Enterprises(in Lakh) & NA & 198.39 & NA & 99.83 \\
\hline 5 & Small Enterprises(in Lakh) & NA & 0.35 & NA & 0.17 \\
\hline 6 & Number of Women Enterprises (in Lakh) & 9.26 & 18.06 & 10.13 & 9.09 \\
\hline 7 & Nature of Activity : Manufacturing (in Lakh) & 33.03 & 104.5 & 36.12 & 52.59 \\
\hline 8 & Nature of Activity : Repair and Maintenance (in Lakh) & 16.93 & 12.31 & 18.5 & 6.19 \\
\hline 9 & Nature of Activity : Services (in Lakh) & 41.5 & 81.93 & 45.38 & 41.22 \\
\hline 10 & Type of Organization :Proprietary (in Lakh) & 88.63 & 187.07 & 96.9 & 94.13 \\
\hline 11 & Type of Organization : Partnership (in Lakh) & 1.04 & 2.65 & 1.13 & 1.33 \\
\hline 12 & Type of Organization : Private Company (in Lakh) & 0.38 & 0.06 & 0.42 & 0.03 \\
\hline 13 & Type of Organization : Cooperatives (in Lakh) & 0.09 & 0.23 & 0.11 & 0.12 \\
\hline 14 & Total Employment(in Lakh) & 187.69 & 408.84 & NA & NA \\
\hline 15 & Total Original Value of P\&M (in Crore) & 24564.92 & 94639.6 & NA & NA \\
\hline 16 & Per Unit Original Value of P\&M (in Lakh) & 0.27 & 0.48 & NA & NA \\
\hline 17 & Total Fixed Investment (in Crore) & 62556.6 & 240816.46 & NA & NA \\
\hline
\end{tabular}




\begin{tabular}{|l|l|l|l|l|l|}
\hline 18 & Per Unit Fixed Investment (in Lakh) & 0.68 & 1.21 & NA & NA \\
\hline 19 & Per Unit Employment & 2.05 & 2.06 & NA & NA \\
\hline 20 & Per Unit Gross Output (in Lakh) & 0.86 & 1.86 & NA & NA \\
\hline 21 & Gross Output per one lakh Fixed Investment(in lakh) & 1.26 & 1.54 & NA & NA \\
\hline 22 & $\begin{array}{l}\text { Gross Output per one lakh Original Value of P\&M(in } \\
\text { lakh) }\end{array}$ & 3.22 & 3.9 & NA & NA \\
\hline 23 & Employment per one lakh Fixed Investment & 3 & 1.7 & NA & NA \\
\hline 24 & Employment per one lakh Original Value of P\&M & 7.64 & 4.32 & NA & NA \\
\hline 25 & Employment per one lakh Gross Output & 2.38 & 1.11 & NA & NA \\
\hline
\end{tabular}

Source: Annual report 2015-16, ministry of MSME.

From the table it is clear that maximum number of MSMEs is in rural areas. And the percentage of units in rural areas has increased from 56.84 in $3^{\text {rd }}$ census conducted in 2001-02 to 60.22 in $4^{\text {th }}$ census conducted in 2006-07. We see a concentration towards rural areas. This is very interesting result. Another interesting result is that $99.83 \%$ of units were micro enterprises and only $0.17 \%$ of units were able to fall in the category of small enterprise. While percentage for medium enterprise is zero. The share of proprietary firm has from $96.9 \%$ to $94.13 \%$ between these two censuses. Total employment generated by MSME sector was equal to 40 million in $4^{\text {th }}$ census while in $3^{\text {rd }}$ census it was 18.7 million. This spectacular rise in employment figures may be contributes to the inclusion of service enterprises in the data collection which were not enumerated earlier. Average size of investment was 1.21 lakh in $4^{\text {th }}$ census against 0.68 lakh in $3^{\text {rd }}$ census. Per unit employment size was 2.06 , not much change from earlier estimates of $3^{\text {rd }}$ census. What is more worrying is the decreasing labour intensity of MSME sector. And use of more capital to produce same number of unit .This is evident from the employment per lakh of fixed investment. Inthe 3 rdcensus this figure was 3 and in $4^{\text {th }}$ census it decreased to 1.7. That means employment generating capacity of MSME hasdecreased. But there is another side of this story. Their more dependence on capital has helped to increase productivity. Gross output per one lakh fixes investment was 3.22 in $3^{\text {rd }}$ census and $4^{\text {th }}$ census it has increased to 3.9.labour productivity has also improved which is also a good sign. In $3^{\text {rd }}$ census to produce out of value of rupee one lakh 2.38 labour was required and now this figure has reduced to 1.11 meaning thereby that to produce same level of output less number of labour is required.

\section{Promotional and Support framework For MSME in India:-}

The central and state governments in India have together set up an elaborate 3 tier structure for promoting the small scale sector:

National level: At national level, in pursuance of the recommendations of International Perspective Planning team (1953-54), several institutions have been set up.

\section{SIDO:-}

A senior official of the Government of India, who is designated as the Development Commissioner for Small Scale Industries (DCSSI), heads SIDO. He is also the ex-officio Additional Secretary in the Ministry of Small Scale Industries; that is, he is second in command in the bureaucratic hierarchy of the Ministry. The Development Commissioner (MSME) have a network of 30 MSME-Development Institute(MSME-DI), $28 \mathrm{Br}$. MSMEDevelopment Institute(Br. MSME-DI), 4 MSME-Testing Centres (MSME-TCs), 7 MSME-Testing Stations (MSME-TSs), 21 Autonomous bodies which include 10 Tool Rooms (TRs) and Tool Design Institutes (TDI), 4 MSME-Technology Development Center(MSME-TDC), 2 MSME-Technology Development CenterFootwear(MSME-TDC), 1 Electronics Service \& Training Centre (ESTC), 1 Institute for Design of Electrical Measuring Instruments (IDEMI) 2 National Level Training Institutes, and 1 Departmental Training Institute and one Production Center.

\section{NSIC:-}

National Small Industries Corporation' (NSIC) is another important institution set up in 1955 that supplies primarily imported machinery on easy finance terms, provides marketing assistance, operates 'Prototype Development and Training Centers' (PDTC) in specific fields such as machine tools, injection molding, leather manufacturing equipment etc. NISIET (now called National Institute of Entrepreneurship and Business Development i.e. NIESBUD) was set up to train and promote personnel, industrial managers and entrepreneurs.

1. Other national level institutions that are supporting the small scale sector are 'National Research Development Corporation' (NRDC), 'Bureau of Indian Standards' (BIS), 'National Productivity Council' (NPC), 'Consultancy 
Development Center' (CDC) and 'Electronics Test and Design Centers' (ETDC). The central financial institutions have also set up the Entrepreneurship Development Institute of India (EDII) at the national level to promote entrepreneurship.

2. All the above mentioned institutions are largely meant for the modern small scale industry. In order to promote khadi and village industries, a separate high level commission has been set up under the Ministry of Industry. Similarly for the handlooms, handicrafts, sericulture and other non-modern small units there are separate divisions to promote them.

\section{State level:-}

The governments have set up institutions as follows:-

1. Small Industry Development Corporations (SIDCs) to develop infrastructure in the form of industrial plots and industrial sheds.

2. State Financial Corporations (SFCs) to provide long term credit facilities

3. State Exports Promotion Corporations to provide marketing assistance for exports from the small scale sector

4. Technical Consultancy Organizations (TCOs) that provide technical, financial and marketing consultancy to the sector

5. Center for Entrepreneurship Development (CEDs) and Institute of Entrepreneurship Development (IEDs) have been set up to promote entrepreneurship through training.

\section{District level:-}

In the year 1978, the central government launched a program of establishing District Industries Centers to provide under a single roof all the support services, clearances, licenses and certificates required by the small entrepreneurs. There are more than 400 such centers, one each in a district.

\section{Institutional Finance for Small Scale Industries:-}

The following agencies through their various schemes provide finance to small scale industries sector under the overall policies and guidelines evolved by Reserve Bank of India.

\section{National Level:-}

a.Small Industries Development Bank of India (Mainly through re-finance) b. National Bank for Agriculture \& Rural Developmentc. National Small Industries Corporation d. Khadi \& Village Industries Commission e. Nationalised Banks

\section{f. Development Commissioner, Small Scale Industries (DCSSI)}

\section{State Level:-}

a. State Financial Corporations (SFCs) b. State Industrial Development Corporation (SIDCs) Infrastructure/Finance c. State Cooperatives Banks d. Khadi \& Village Industries Board

\section{Regional \& District Level:-}

a. Regional Rural Banks (RRBs) b. District Central Cooperative Banksc. Primary Cooperative Banksd. Branches of State level institutions \& nationalised banks about 65,000 in number e. Khadi \& Village Industries Commission f. District Industries Center (DIC)

\section{Scope and Conclusion:-}

Indian economy is a very fast growing economy. It has recently surpassed the Chinese economy in terms of growth rate. This throws huge opportunities to MSMEs in India than ever for expansion and diversification across the sectors. There are various sectors like manufacturing, Precision Engineering Design, Agro \& Food Processing, Pharmaceuticals, Textile \& Garments, Retails IT and Service Sector, where MSMEs have huge potential. After globalization technological changes enhance opportunities and improve physical resources to generates ideas and translate them into economic and social value. Banks are also providing credit for empowering them. Consistent policy support is also increasing opportunities of MSMEs. No doubt MSMEs have huge opportunities but they still face a numberof problems such as a. Absence of adequate credit from Banks b. Limited Capital and Knowledge c. Non - Availability of proper Information Technology d. Lower capacity of production e. Lack of marketing strategy f. Identification of new marketing. Challenge of getting skilled low cost labour. 


\section{References:-}

1. DileepAthavale ( Feb 27, 2013 ),”Small companies ,s big business “, Timesof India .

2. Sudhavenkatesh, KrishnaveniMuthiah, "SMEs in India: Importance and Contribution,Asian Journal of Management Research, volume 2 Issue 2 2012,

3. Annual report 2015-16 Ministry of Micro,Small and Medium Enterprises - ( MSME) of India, Government of India 